\title{
TARGET AND LEARNING NEEDS IN ENGLISH FOR MIDWIFERY STUDENTS
}

\author{
Diyah Nur Hidayati \\ diyah.nurhidayati26@yahoo.co.id \\ Sri Haryati \\ nafisahatiku@gmail.com \\ Universitas Sebelas Maret Surakarta
}

\begin{abstract}
Teaching English for midwifery students is categorized as English for Specific Purposes (ESP). In this course, need analysis need to be conducted to discover what students already know, what they need to know, and what they want to know. To this end, the study investigated the target needs and learning needs of midwifery students. A total of 53 students responded to a questionnaire and open-ended interview. The results demonstrated that students wanted to be able to communicate English fluently. Also, they wanted to understand various English texts related to their midwifery field. The result also showed that most students were at the beginner level indicating that they were just able to understand simple sentences and expressions used in a daily life. Regarding learning needs, students preferred to have the input text in the form of dialogue and monologue provided with pictures with the length of the texts of less than 150 words and between 150-250 words. According to the results obtained from this study, it can be concluded that need analysis needs to be conducted before giving the English course based on the students' field study.
\end{abstract}

Keywords: ESP, need analysis, midwifery students

\section{INTRODUCTION}

This study is to analyze the target needs and learning needs of midwifery students in tertiary level. According to the vision of the midwifery department, upon graduation students are expected to be able to compete in the global market. This is based on the data of BNP2TKI that the Indonesian nurses and midwifery are surplus. Many students graduating from nursing and midwifery department are difficult to get ajob. To deal with this case, the government attempts to find the solution by helping the graduate students to find the job in other countries. Still, there is a gap between the quality and competency of health graduate students with the demands from the global. One of the challenges is that the lack of English and target language that have to be mastered by students who want to work abroad. To fulfill this gap, therefore, the government encourages health students especially midwifery students to upgrade their skills by learning English. The crucial need of English for midwifery students is to assist them to compete in the global market (Susanto \& Latief 2016).

Talking about midwifery students is closely related to English for Specific Purposes (ESP). Teaching English for midwifery students are abranch of ESP since General English (GE) courses do not meet learners' needs (Saliua \& Hajrullaia 2016). It deals with 'teaching and learning English for the particular purpose and field' (Otilia 2015). Its course focuses on the specific field delivered in English with specific vocabulary, terms, and other relevant things (Chung \& Chang 2017; Saliua \& Hajrullai 2016). It is based on a particular context and the learners' specific needs (Otilia 2015; Adhabiyya et al 2014). It is conducted to meet students' future career needs. Students who learn English based on their field 
study will be easier to find a job in accordance with their study program. It is believed that students will be more highly motivated in learning about topics and texts which are related to their study or work areas. Saliua \& Hajrullai (2016) hypothesize their result of the study that conducting ESP course is very fruitful for their students who want to work in the labor market or in international organizations. The students reach higher communicative competence in their field study (Lee 2016). To do so, the factors of ESP instruction need to take account: the learner, the language chosen, and the learning context (Chung \& Chang 2017). Those factors are dealing with need analysis.

Need analysis is crucial to be done by Midwifery students before learning English. It is the basic principle of ESP (Robinson in Boroujeni \& Fard 2013; Kothalawala 2015). It is to assess 'the communicative needs of the learners and the techniques of achieving specific teaching objectives' (Otilia 2015). The previous studies conducted by Aliakbaria \& Boghayerib (2014) highlight that the textbook, topics, and length of the course do not meet the students' need. Thus, it needs to conduct need analysis to develop ESP language course in accordance with the 'target discipline' (Chostelidou 2010; Aliakbaria \& Boghayerib 2014; Saliua \& Hajrullai 2016). Need analysis is the 'cornerstone' of lesson plans, syllabus design, material evaluation and development, and instructional design and assessment development (Widodo 2017; Benaventa \& Reyes 2015).

In addition, Hutchinson \& Waters (1987, 54) state that need analysis covers target needs and learning needs. Target needs are what the learners need to do in the target situation. Then, learning needs are what the learners need to do in order to learn. Conducting needs analysis has to consider necessities, lacks, and wants.

Necessities are what learners have to know in order to function effectively in the target situation. It is a matter of observing what situations the learner will need to function in and analyzing the constituent parts of them. Meanwhile, lacks are what the learner knows already in the target situation. It would be useful to decide which of the necessities that the learners lack. It can be defined as the gap between the target proficiency and the present existing proficiency of the learners. Also, wants are the learner's point of view related to what they want to learn.

In addition, Graves $(2000,153)$ explains that the procedures of need analysis include the series of decisions, actions, and reflections that are breaking down into: (1) deciding what information to gather and why, (2) deciding the best way to gather it: when, how, and from whom, (3) gathering the information, interpreting the information, (5) acting on the information, 6) evaluating the effect and effectiveness of the action,(7) deciding on further or new information to gather.

According to the research conducted by Poedjiastutie \& Oliver (2017), there is no 'systematic analysis of students' needs' dealing with curriculum development and classroom instruction for the ESP courses. Indeed, Kazar and Mede (2015) highlight that 'the effective use of strategies in given tasks' is needed to be the priority to enhance students' English skills. Indeed, the tasks and activities of four English skills are the focus of this study. Stern (in Otilia 2015) distinguishes 'proficiency objectives' of learning English which refer to the mastery of the four language skills: reading, writing, listening, and speaking.

Accordingly, the issue of the needs of English for midwifery students has not been examined much, and the relevant information is scarce. The study, therefore, seeks the answer to the following questions:

1. What are the target needs of the 
midwifery students?

2. What are the learning needs of the midwifery students?

\section{RESEARCH MeTHODS}

This study was a descriptive study. The sample included 53 students of midwifery department in Surakarta, Indonesia. The main data of this study was a questionnaire that was distributed to know the learning needs and target needs. The subjects were asked several questions about their learning needs by answering multiple choice questions. To support the data, an open-ended interview was employed as well. The organization of the questionnaire is presented in Table 1. researcher according to the recurring words and ideas. Finally, the supporting quotes from each participant were listed and discussed.

\section{Findings AND Discussions}

Needs analysis aimed to find out the learners' target needs and learning needs. Target needs cover necessities, lacks, and wants while learning needs consist of input, procedure (activities), setting, learners' role and teacher's role. Yet, this study just concerned on input and procedures since the researchers believed that setting, learners' and teachers' role could be negotiatedwhen teaching and learning process was held.

In this study, the researchers

Table 1: The Organization of Questionnaire

\begin{tabular}{|c|c|c|c|}
\hline Aspects & Item & Questionnaire Purpose & Reference \\
\hline Necessities & 1 & $\begin{array}{l}\text { To find out what the learners need in the } \\
\text { target situation for their job at the time. }\end{array}$ & $\begin{array}{l}\text { Hutchinson \& } \\
\text { Waters }(1987,55)\end{array}$ \\
\hline Wants & 2 & $\begin{array}{l}\text { To find out what the students want to be } \\
\text { included in the materials. }\end{array}$ & $\begin{array}{l}\text { Hutchinson \& } \\
\text { Waters }(1987,56)\end{array}$ \\
\hline Lacks & 3 & $\begin{array}{l}\text { To find out the gap between what the } \\
\text { students have known and what they } \\
\text { should know. }\end{array}$ & $\begin{array}{l}\text { Hutchinson \& } \\
\text { Waters }(1987,55 \text { - } \\
56)\end{array}$ \\
\hline Inputs & 5-13 & $\begin{array}{l}\text { To find out the spoken, written, and } \\
\text { visual data that should be included in } \\
\text { the material. }\end{array}$ & Nunan $(2004,47)$ \\
\hline Procedures & $14-20$ & $\begin{array}{l}\text { To find out what the students should do } \\
\text { with the input within the tasks. }\end{array}$ & Nunan (2004: 52) \\
\hline
\end{tabular}

The data obtained from the questionnaire were analyzed quantitatively. The data were, then, presented using charts and tables in percentages and interpreted in the form of paragraphs. The quantitative data were analyzed to yield frequencies and percentages of respondents checking each respond category on particular closed-form questions (Borg \& Gall 2007, 242). In addition, an open-ended interview was used as the additional data to strengthen the quantitative data. The interviews were first transcribed, and then by reading each participant's transcripts, the conceptual themes were identified by the administered the questionnaires of lists of possible statements based on the target needs and learning needs to get students in order of preference. By doing so, the researchers could compare students' different lists and come to a consensus view of what the class as a whole want and needs. Here is the detailed explanation of the research results.

\section{Midwifery Students' Target Needs}

The analysis of the target needs is divided into three points; necessities, wants, and lacks.

\section{Necessities}

Necessities are related to what students have to know (Hutchinson \& 
Waters 1987). The questionnaires' result showed that students learned English because they wanted to able to communicate in English both spoken and written forms (72\%). Others said that English was needed to support their future job as a midwifery (66.6\%) as well as the higher education they wanted to obtain. Several students also focused on experiencing the English language and its cultures (42\%). Even, $32 \%$ students learned English to widen their connection around the world.

\section{Wants}

'Wants' cover what students want to know (Hutchinson \& Waters, 1987). The data show that most students wanted to understand a variety of texts in English $(64.7 \%)$ and English vocabulary including the appropriate meaning and pronunciation (64.7\%). Of course, several wanted to speak English well (58.8\%), whereas small number just wanted to comprehend expressions in English (43.1\%). that they were curious enough to learn English for Midwifery. They wanted to get ready for ASEAN Economic Community (AEC). Therefore, they needed to learn not only written English but also spoken English.

Here are some results of the interview on students (S) wants.

S1 : want to communicate well with the patients/clients

$\mathrm{S} 2$ : explain the materials related to the midwifery field since we have to compete in this Asian Economic Community (AEC). Therefore, we have to speak English well.

S3 : the material related to the midwifery and the work system in other countries.

$\mathrm{S} 4$ : the material needed in the midwifery field.

S7 : of course, the material related to the midwifery, and the most important thing can communicate well.

S8 : Speaking, reading, and listening because they are very important our job, when we get a good job, because English must be one of the job qualifications such as in Sarjito hospital. Besides, there are many import medicines written in English. Then,

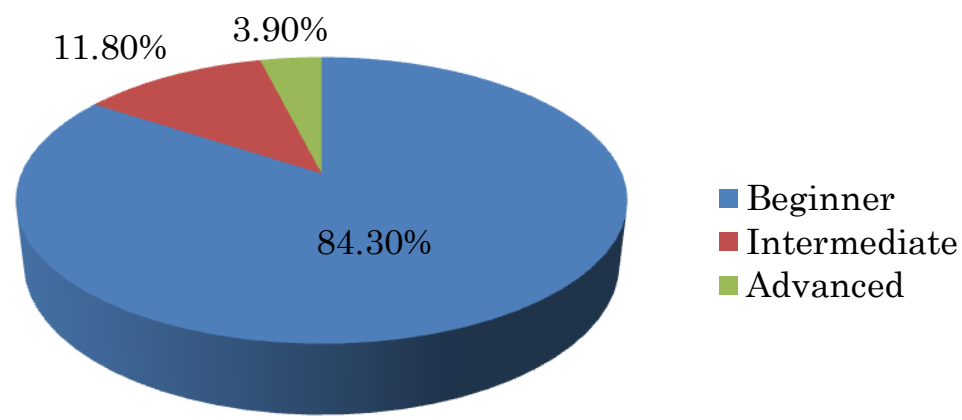

Chart: Midwifery Students' Levels of English

In relation to the topic, the students wanted to learn English related to the midwifery (84.3\%). The rest was related to daily life in family, school, and society (66.7\%). For the additional materials, students also wanted to learn English in politics, economics, sociocultural life, religion, and law.

These data were supported by the result of the interviews. Most students wanted to learn English in order that they could communicate well when they had foreigner's' patients. They also said when we have foreigner patients who cannot speak theIndonesian language, we also have to speak English.

S9 : the material related to the midwifery field and the material that can be used to communicate in daily life.

\section{Lacks}

'Lacks' is the gap between what students have already known and what they have not known (Hutchinson \& Waters 1987). The Chart indicates that almost all students of midwifery department were at the beginner level. 
It means students were just able to understand simple sentences and expressions used in a daily life (84.3\%). Also, $11.8 \%$ students admitted that they could understand the main idea or purpose of complicated texts and gave comments about that. Just few students could understand a variety of texts and understand implicit ideas in a text.

\section{Midwifery Students' Learning Needs}

The learning needs are related to what students need to learn (Hutchinson \& Waters 1987). The analysis was focused on macro and micro skills of listening, speaking, reading, writing, grammar, information of the text (42.1\%), the meaning and pronunciation (31.4\%), and specific expressions of the text $(23.5 \%)$. In this case, theaudio material was used as the main input texts in the listening activities. These data are supported by the following interview results.

S1 : self-introduction, explaining medical procedures, communicating with many people, etc.

S2 : speaking, writing anessay, medical reports, how to take care patients, apresentation about research/journal publication, how to do a good discussion.

S3 : daily expression especially conversations in hospital settings, about the midwifery field.

Table 2: The Result of the Input Texts and the Lengths of the Texts

\begin{tabular}{lll}
\hline \multicolumn{1}{c}{ Skill } & \multicolumn{1}{c}{ Input Text } & \multicolumn{1}{c}{ Text Length } \\
\hline Listening & Monologue and dialogue with pictures (88.2\%) & $<150$ words (52.9\%) \\
Speaking & Monologue and dialogue with pictures (72\%) & $150-250$ words (52.9\%) \\
Reading & Monologue with pictures & $150-250$ words \\
Writing & New vocabularies related to the text & $150-250$ words \\
\hline
\end{tabular}

pronunciation, and pronunciation. Every skill included input texts, the length of the text, and procedures. 'Input' refers to the spoken, written and visual data that learners work within the course of completing a task (Nunan 2004, 109). It can be letters, picture stories, memo, notes, drawings, family trees, photographs, shopping lists, street maps, menus, recipes, etc. In addition, the procedure refers to the activity that students are going to do based on the input (Nunan 2004, 109). The input texts and the lengths of the texts are presented in Table 2.

In consideration of the data in the table, $88.2 \%$ students preferred the monologues and dialogues with pictures. The length of the text that the students requested was $<150$ words (52.9\%) and 150-250 words (43.1\%). In addition, the students expected the listening activities by identifying the content of the text (56.9\%), the detail
Based on those interviews, students requested to learn about selfintroduction, medical procedures, medical reports, patients' care procedures. Also, they wanted to learn about daily expressions in hospital settings. Of course, all of that topic had to be related to the midwifery field. The data is ideal compared to the theory of listening skills proposed by Harmer (2007, 304). Audio material is able to encourage students to accustom to listen to different voices with various characters like the real situation where people are talking. Still, students need to have a gist of a story such as a series of pictures in order to predict the topic being discussed (Harmer 2007, 311). Table 3 presents the result of activities based on the students' questionnaires.

Since the course requires an integrated skill, the speaking skill is the result of the receptive skill, listening. This is the stage where 
students have to produce what they have already got from the listening activity. Thus, various classroom speaking activities such as acting from a script or dialogues, communication games, discussion, prepared talks,
$43.1 \%$ students preferred the text consisting of less than 150 words. Additionally, students wanted to have speaking activities by practicing a model of dialogue or monologue $(52.9 \%)$, doing a role play (37.7\%), making a

Table 3: The Result of Listening, Speaking, Reading, and Writing Activities

\begin{tabular}{|c|c|c|}
\hline Skill & Activities & Percentage \\
\hline \multirow{4}{*}{ Listening } & identifving the content of the text & $56.9 \%$ \\
\hline & identifying the detail information of the text & $42.1 \%$ \\
\hline & identifying the meaning and pronunciation & $31.4 \%$ \\
\hline & identifying specific expressions of the text & $23.5 \%$ \\
\hline \multirow[t]{6}{*}{ Speaking } & practicing a model of dialogue or monologue & $52.9 \%$ \\
\hline & doing a role play & $37.7 \%$ \\
\hline & making a dialogue then practicing it & $37.3 \%$ \\
\hline & $\begin{array}{l}\text { discussing a topic and giving opinion related to } \\
\text { the topics }\end{array}$ & $31.4 \%$ \\
\hline & $\begin{array}{l}\text { presenting a report, story, speech or discussion } \\
\text { result }\end{array}$ & $27.5 \%$ \\
\hline & $\begin{array}{l}\text { interviewing other friends related to the topics } \\
\text { being discussed }\end{array}$ & $21.6 \%$ \\
\hline \multirow[t]{6}{*}{ Reading } & reading a text to find thegeneral idea of the text & $58.8 \%$ \\
\hline & reading a text answer the questions & $47.1 \%$ \\
\hline & reading a text detail information & $37.3 \%$ \\
\hline & arranging jumbled paragraphs & $23.5 \%$ \\
\hline & discussing meaning in thecontext & $23.5 \%$ \\
\hline & summarizing the content of the text & $11.8 \%$ \\
\hline \multirow[t]{6}{*}{ Writing } & arranging jumbled words to be a good sentence & $47.1 \%$ \\
\hline & $\begin{array}{l}\text { writing a text based on pictures, tables, } \\
\text { diagrams, or graphics }\end{array}$ & $45.1 \%$ \\
\hline & $\begin{array}{l}\text { writing the same text as the given model text } \\
\text { based on the correct grammar and sentence } \\
\text { structures }\end{array}$ & $43.1 \%$ \\
\hline & $\begin{array}{l}\text { correcting wrong sentence structures, } \\
\text { spellings, and punctuations }\end{array}$ & $29.4 \%$ \\
\hline & writing a conclusion of a text & $17.7 \%$ \\
\hline & $\begin{array}{l}\text { and completing the missing words with your } \\
\text { own words }\end{array}$ & $17.6 \%$ \\
\hline
\end{tabular}

questionnaires, and simulation and role-play are appropriate to be applied in the speaking activity (Harmer 2007, 348-353). The finding of the study revealed that $72 \%$ students chose monologues and dialogues with pictures as their input text. The text had to consist of 150-250 words (52.9\%). Yet, dialogue then practicing it (37.3\%), discussing a topic and giving opinion related to the topics (31.4\%), presenting a report, story, speech or discussion result $(27.5 \%)$, and interviewing other friends related to the topics being discussed (21.6\%). Based on the interview, students wanted to learn how 
to communicate with others using Standard English in their workplace. They also wanted to acquire various different methods to master English. Still, they wish to learn about public speaking.

S1 : conversation about the midwifery field,

S2 : how to communicate with others. Need more different methods so all students can do well.

Not all students can speak English well.

S3 : Public speaking using English that is used in daily communication and in the midwifery field.

Furthermore, students also have to practice their understanding of texts by doing reading activities. The result of the study showed that $68.6 \%$ students wanted to have a reading text with pictures. The length of the texts was 150- 250 words $(52.9 \%)$ and $<150$ words (35.3\%). Also, students preferred reading a text to find thegeneral idea of the text $(58.8 \%)$, answer the questions (47.1\%), and detail information (37.3\%). They also requested to have activities in the form of arranging jumbled paragraphs (23.5\%), discussing meaning in context (23.5\%), and summarizing the content of the text (11.8\%). To complete all those activities, students need to learn the reading techniques in the form of skimming and scanning (Harmer 2007, 288). Skimming uses to seek general information rather than reading for comprehension. The skimming strategies include reading the first and last paragraphs using headings, summarizes, and other organizers. Also, this strategy is good to find the title, subtitles, subheading, and illustrations. On the other hand, scanning is related to find specific pieces of information. This strategy is used to find out a fact or detail or a particular information.

The production skill of reading is writing skill. According to the data, the length of the text for the writing was $150-250$ words $(66.7 \%)$ and $<150$ words (25.5\%). The writing activities that the students wanted were arranging jumbled words to be a good sentence (47.1\%), writing a text based on pictures, tables, diagrams, or graphics (45.1\%), writing the same text as the given model text based on the correct grammar and sentence structures (43.1\%), correcting wrong sentence structures, spellings and punctuations (29.4\%), writing a conclusion of a text (17.7\%), and completing the missing words with your own words (17.6\%). In this respect, the writing activities have to follow the proses of writing such as pre-writing, drafting, reviewing and revising, and rewriting. The proses of rewriting include revising structure and content, proofreading, and making final corrections (Zemach \& Rumisek 2003, $3)$.

In addition, the students need to master the micro skills including vocabulary, grammar, and pronunciation in order to perform well all the macro skills (listening, speaking, reading, and writing). Those skills are embedded with the macro skills. Table 4 explains the result of the micro-skills activities.

In the EFL textbook, vocabulary is generally addressed as part of a reading comprehension exercise in each chapter. However, it can also be put in the listening activity integrated or other skills. Analyzing the data of vocabulary activities, the students preferred matching words with pictures provided (60.8\%), classifying new vocabulary on a table then finding the meaning based on the context $(39.2 \%)$, finding new vocabulary on a text and finding the meaning on a dictionary (35.3\%), and searching the synonyms or antonyms of words (35.3\%). The interview data also show that students wanted to improve their vocabulary mastery related to the midwifery field. The result is in line with the theory proposed by Harmer. Teaching vocabulary cannot be separated from its context and distribution (Harmer 2007, 229).

S1 : vocabulary and grammar about health. 
S2 : of course, vocabulary about midwifery and speaking to support the future education.

S3 : .... vocabulary about the midwifery field. dictionary (13.5\%). The result of the interview also showed the same result. The students wish to learn how to pronounce the English word correctly.

Table 4: the Result of Vocabulary, Grammar, and Pronunciation Activities

\begin{tabular}{|c|c|c|}
\hline Skill & Activities & Percentage \\
\hline \multirow{4}{*}{ Vocabulary } & matching words with pictures provided & $60.8 \%$ \\
\hline & $\begin{array}{l}\text { classifying new vocabulary on a table then finding } \\
\text { the meaning based on the context }\end{array}$ & $39.2 \%$ \\
\hline & $\begin{array}{l}\text { finding new vocabulary on a text and finding the } \\
\text { meaning on a dictionary }\end{array}$ & $35.3 \%$ \\
\hline & searching the synonyms or antonyms of words & $35.3 \%$ \\
\hline \multirow[t]{5}{*}{ Grammar } & doing grammar exercises & $70 \%$ \\
\hline & $\begin{array}{l}\text { identifying and correct the wrong sentence } \\
\text { structures }\end{array}$ & $40 \%$ \\
\hline & $\begin{array}{l}\text { completing the missing words on the text based on } \\
\text { the context }\end{array}$ & $36 \%$ \\
\hline & memorizing sentence structure/grammar patterns & $30 \%$ \\
\hline & writing sentences based on the given pattern & $22 \%$ \\
\hline \multirow[t]{4}{*}{ Pronunciation } & $\begin{array}{l}\text { pronouncing every sentence including the stress and } \\
\text { intonation }\end{array}$ & $73.1 \%$ \\
\hline & $\begin{array}{l}\text { listening and repeating the pronunciation from the } \\
\text { teacher }\end{array}$ & $69.2 \%$ \\
\hline & searching the pronunciation on a dictionary & $32.7 \%$ \\
\hline & $\begin{array}{l}\text { reading aloud and looking for the pronunciation on } \\
\text { a dictionary }\end{array}$ & $13.5 \%$ \\
\hline
\end{tabular}

For the grammar activities, students wanted to do grammar exercises $(70 \%)$, identify and correct the wrong sentence structures (40\%), complete the missing words on the text based on the context (36\%), make a text as the need of graphic designers (34\%), memorize sentence structure/grammar patterns (30\%), and make your own sentences based on the given pattern $(22 \%)$. That result is in accordance with students' interviews.

S1 : Grammar, vocab, and noun about midwifery

The pronunciation activities were learning to pronounce every sentence including the stress and intonation (73.1\%), listening and repeating the pronunciation from the teacher $(69.2 \%)$, searching the pronunciation on a dictionary (32.7\%), and reading aloud and looking for the pronunciation on a
S1 : how to pronounce the word correctly in English.

\section{CONCLUSION}

English for Specific Purposes concerns on teaching English for aparticular field in order to help students acquire English according to their future career. Here, midwifery department is one of the examples that employ ESP as the compulsory subject. Therefore, the need of conducting need analysis cannot be denied to know what students really want and/or prefer to achieve the best result during the teaching and learning process.

This research takes its starting point from analyzing of target needs and learning needs. The result shows that the students need to learn English so that they can communicate well. During the learning process, they want to learn English for Midwifery. 
However, they are still at the beginner level in which they just understand simple sentences and daily expressions. They still need to expose their English to achieve the goal. In addition, the learning needs data indicate that the input text requested by the students is in the form of dialogue and monologue provided with pictures with the length of less than 150 words and/or 150-250 words.

The result of this research is able to be used by the future researchers to design syllabus or materials for midwifery department. Also, the concept of this research can also be adapted to analyze students' needs for another department. Yet, the researchers suggest that the specific topics must be included based on what students are being learned.

\section{REFERENCES}

Adhabiyyah, R et al. 2014. "Needs Analysis and Material Development in English for Specific Purposes in Relation to English for Islamic Studies". E-proceedings of the Conference on Management and Muamalah (CoMM 2014): 26-27 May 2014

Aliakbaria, M. \& M. Boghayerib. 2010. "Needs Analysis Approach to ESP Design in Iranian Context." Procedia: Social and Behavioural Sciences 2: 4507-4512

Benaventa, GT \& SS Reye. 2015. "Target Situation as a Key Element for ESP (Law Enforcement) Syllabus Design". Procedia: Social and Behavioral Sciences, 173 (2015): 143-148

Borg \& Gall. 2003. Educational Research: An Introduction (7th edition). New York: Pearson Education

Boroujeni, SA \& Fard, FM. 2013. "A Needs Analysis of English for Specific Purposes (ESP) Course For Adoption of Communicative Language Teaching: A Case of Iranian First-Year Students of Educational Administration". International Journal of Humanities and Social Science Invention 2 (6): 3544

Chostelidou, Dora. 2010. “A Needs
Analysis Approach to ESP Syllabus Design in Greek Tertiary Education: A Descriptive Account of Students' Needs". Procedia Social and Behavioral Sciences 2: 4507-4512

Chung, K \& C Chang. 2017. "From EAP to ESP: A Teacher Identity Development". Taiwan Journal of TESOL. 14 (2): 71-100

Graves, Kathleen. 2000. Designing Language Courses. Canada: Heinle \& Heinle Publisher.

Hardum, Siprianus Edi. Perawat dan Bidan Bisa Terserap di Luar Negeri $<$ http://www.beritasatu.com/ekonomi/4 05232-perawat-dan-bidan-bisaterserap-di-luar-negeri.html>

Harmer, Jeremy. 2001. The Practice of English Language Teaching (4th edition). London: Pearson Education/Longman.

Hutchinson, Tom \& Alan Waters. 1987. English for Specific Purposes: A Learning-Centered Approach. Cambridge: Cambridge University Press.

Kazar, SG \& E. Mede. 2015. "The Perceptions Of ESP Students' Target Needs: A Case Study". Procedia: Social and Behavioral Sciences, 191: 2526 2530

Kothalawala, JC. 2015. "Tracing the Development of Approaches of Needs Analysis in English for Specific Purposes (ESP)". Proceedings of 8th International Research Conference $K D U$

Lee, Chin-Ling. 2016. "Principles and Practices of ESP Course Design-A Case Study of a University of Science and Technology". International Journal of Learning, Teaching and Educational Research, 15 (2): 94-105

Nunan, David. 2001. Designing Tasks for the Communicative Classroom. Cambridge: Cambridge University Press.

Otilia, SM. 2015. Needs Analysis In English For Specific Purposes. Academic Branchusi

Poedjiastutie, D \& R Oliver. 2017. "English Learning Needs of ESP Learners: Exploring Stakeholder Perceptions at an Indonesian University”. TEFLIN Journal. 28 (1) 
Diyah Nur Hidayati \& Sri Haryati

Saliua, B \& H Hajrullaia. 2016. "Best Practices in the English for Specific Purpose Classes at the Language Center". Procedia: Social and Behavioral Sciences 232: 745-749

Susanto, J and Latief, MA. 2016. Developing English Teaching Material for Midwifery Students

Widodo, HP. 2017. "Approaches to Needs Analysis in ESP Curriculum Development". The European Journal of Applied Linguistics and TEFL, 6 (1): 127-146 